\title{
Photosynthetic Efficiency Promotion of Sugar Beet by Formulation of Trichoderma and Control of Some Sugar Beet Disease Seedling
}

Heidi I.G. Abo-EInaga*

Plant Pathology Department, Faculty of Agriculture, Assiut University, Assiut 71526, Egypt

*Corresponding author: Heidi I.G. Abo-Elnag, Plant Pathology Department, Faculty of Agriculture, Assiut University, Assiut 71526, Egypt, Tel: 20882412838; Fax: 20882412838; Email: heidiaboalnaga1@yahoo.com

Rec date: Mar 21, 2014, Acc date: July 08, 2014, Pub date: July 10, 2014

Copyright: @ 2014 Elanga HIGA, This is an open-access article distributed under the terms of the Creative Commons Attribution License, which permits unrestricted use, distribution, and reproduction in any medium, provided the original author and source are credited.

\begin{abstract}
Four isolates of Fusarium sambucinum(Fuckel) (isolates 1,2,3,4)and four isolates of Fusarium solani ( Mart.) Sacc .(isolates5, 6, 7, 8)were isolated from different localities of sugar beet in Assiut Government .The tested isolated were pathogenic to sugar beet oskarpoly variety causing damping off and root rot. Isolates 2 and5 had the highest pathogen city to sugar beet isolates 3 and 8 had the lowest pathogen city pathogen city. Trichoderma viride have been used for their potential antagonism for controlling Fusarium sp damping off and root rot disease of sugar beet. In vitro studies showed that the culture filtrate of Trichoderma viride significantly decreased the growth of the tested isolates of both Fusarium sambucinum and Fusarium solani Treating the soil with formulation of Trichoderma viride before planting decreased damping off and root rot of sugar beet compared with untreated and untreated soil with formulation of Trichoderma viride under greenhouse conditions during growing seasons 2010and 2011.Chlorophyll a chlorophyll $b$ and total chlorophyll carotenoids decreased when treatment the infested soil with either Fusarium sambucinum or Fusarium solani compared with untreated and untreated soil with formulation of Trichoderma viride.
\end{abstract}

Keywords: Fusarium sp; Trichoderma virid; Photosynthetic; Sugar beet

\section{Introduction}

Sugar beet (Beta vulgaris L.) is one of the important sugar crops in Egypt as well as all over the world. Sugar beet is considered the second most important source of sugar. Sugar beet is attacked by some Fusarium species causing damping - off and root rot disease which is considered to be one of most destructive and serious disease in many parts of the world as well as in Egypt [1-3] Biocontrol technologies have gained momentum in disease control of crop plants in recent times as these technologies not only minimize of replace the usages of harmful chemical pesticides but also found to be cheaper and efficient in certain disease control programmers. Successful use of fungal biocontrol agents like Trichoderma spp agents that commercially produced to prevent development of several soil pathogenic fungi [4-6]. Different mechanisms control soil born disease caused by pathogens. Rhizoctonia ,Sclerotium, Fusarium, Pythium and Phophthora in several crops have been reported [7]therefore using biological control such as T.viride which is one the efficient biocontrol have been suggested as being responsible for their bio-control activity which includes mycoparasitism, antibiosis, competition for nutrients and space .Secretion of chitinolytic enzymes[8].The major aspects of successful biological control technologies include the establishment of product, formulation and delivery system for microorganism that enable them for efficient disease control.The mass production systems should be complete with industrial and commercial development methods and field application [9] 2010. Trichoderma spp can be formulated as pellets [9-10] dusts and powders [11] Striking changes in the amount and distribution of photosynthetic pigment result from the infection by obligated parasite [12] This work aimed to study the effect of Trichoderma viride on growth activates of Fusarium sambucinum or Fusarium solani in vitro .The effect of formulation Trichoderma viride in reducing caused by Fusarium sambucinum and Fusarium solani disease incidence Assess Photosynthetic efficiency changes associated with disease development after treatment with Trichoderma viride.

\section{Material and methods}

\section{Isolation:}

Natural diseased sugar beet plants showing damping off symptoms were collected from different locations of Assiut Governorate for pathogens isolations. Isolation technique was carried out according to [1] isolated fungi were purified using single spore and hyphen tip technique and identified according to descriptions in the manual of 13-14] Then confirmed by Assiut University Mycological center (AUMC).

\section{Soil infestation}

Inoculums of the isolated Fungi Fusarium sambucinum (isolate1 Assiut isolate 2 Assiut isolate 3 Manfulate isolate and 4 Assiut) and Fusarium solani, (isolate 5Assiut isolate 6 Manfulate isolate 7 Assiut isolate and 8 Assiu isolate T, were prepared individually on barley grain medium [15] for artificial infestation. Fourteen days old culture of each pathogen was used for the infestation of sterilized soil 7 days before sowing. Inoculums of each pathogen were applied to the autoclaved soil at the rate $5 \%$ by weight. Ten sugar beet seeds of variety oscarpoly were sown in each pot $(25 \mathrm{~cm}$ in diameter) and watered. Four replicates represented each treatment and four pots filled with uninfected soil were used as control. The percentage of pre and post emergence damping off, survival seedlings and disease index for 
seedlings were recorded after 21 and 45 days, respectively from planting.

\section{Trichoderma isolation}

\section{Evaluation of antagonistic activity of Trichoderma viride, In dual culture technique (in virto)}

The microorganism was isolated from rhizosphere of sugar beet according to [16] $T$. viride was carried out according to [17] by using dual culture technique. Fusarium sambucinum (isolates 1,2,3,4) and Fusarium solani, (isolates 5, 6, 7,8) separately, on PDA medium for 7 days at $25^{\circ} \mathrm{C}$. Disc (5mm - diameter) from each bio-control fungus was inoculated on surface of PDA medium in side of Petri dish. A disc (5 mm - diameter) of Fusarium sambucinum (isolates 1,2,3,4) and Fusarium solani, (isolates $5,6,7,8$ ) separately was inoculated at equal distance of the opposite side of Petri dish. Petri dishes were inoculated with each pathogenic fungus only as control. Three Petri dishes for each bio-control-pathogenic fungus treatment as well as the control were used as replicates. The inoculated Petri dishes were incubated at $25^{\circ} \mathrm{C}$ at 7 days when the pathogen fungi covered the plate surface of the control treatment, and then $T$. viride and pathogens were evaluated based on radial growth of colony of pathogen, over growth of Trichodermia.

Antagonistic effect of $T$. viride as decrease of the mycelia growth of pathogenic fungi was determined using the following formula:

Where,

A: The diameter of mycelia growth of pathogenic fungus in control

B: The diameter of mycelia growth of pathogenic fungus with Trichoderma fungus.

\section{Culture filtrate (Nonvolatile metabolites) and early volatile metabolites tests}

Mycelia disks of each Trichoderma isolate grew on 1/4-strengh PDA was separately inoculated into $100 \mathrm{ml}$ flasks containing potato dextrose liquid and incubated at 20 to $29^{\circ} \mathrm{C}$ and $120 \mathrm{RPM}$ in rotary shaker incubator for 10 days. The cultures were then filtered through $0.22 \mathrm{~mm}$ Millipore filters and $15 \mathrm{ml}$ of these filtrates were added into sterile Erlenmeyer flasks containing 50ml 1/4-strength PDA with $25 \%$ further agar at $45^{\circ} \mathrm{C}$. After medium solidifying, mycelia disks of Fusarium sambucinum (isolates 1,2,3,4). and Fusarium solani, (isolates $5,6,7,8)$ separately individually agent derived from actively growing colonies were placed on one edge of medium plates and were incubated at $25 \pm 3^{\circ} \mathrm{C} ;[18-19]$. For early volatile metabolites test, pathogen and Trichoderma actively growing colonies were subculture on PDA and incubated in dark condition at $25^{\circ} \mathrm{C}$. Then, opened Petri dishes containing $48 \mathrm{~h}$ old colony agent Fusarium sambucinum(isolates 1,2,3,4) and Fusarium solani,(isolates 5, 6, 7,8) separately placed on $24 \mathrm{~h}$ old colony of Trichoderma and were airtight using parapylm. Control was Petri dishes containing PDA medium. The Petri dishes were incubated in the same temperature and dark conditions . Radial growth on pathogen was measured daily in both tests. Inhibitory percentages were calculated by Above Formula.

\section{Inoculums preparation of antagonistic Trichoderma}

For mass production they were grown in $1000 \mathrm{ml}$ conical flasks each containing $250 \mathrm{ml}$ vermiculate 250 wheat bran and $250 \mathrm{ml}$
Medium( C ZDIFCO) and autoclaved for $20 \mathrm{~min}$ at 121 on two consecutive days.The flasks were inoculated with the antagonist fungus and incubated at $20 \mathrm{C}^{\circ}$.After incubation period, contents of flask were transferred to plastic plate under sterile conditions left to dry and then mixed in a blander to dry then mixed in a blender to become powder T.viride mixture contains 10x108 and was kept in poly ethylene bags at room temperature until used

\section{Antagonistic effect of formulation of $T$. Viride against The causative pathogen of sugar-beet damping off and root rot disease under greenhouse conditions}

Applied formulation of $T$. viride at the rate $5 \%$ weight of the soil one week before planting the seed.The same method preparation the inoculum pathogens and infestation the soil as is described in pathogenicity test

\section{Chemical Assessment}

Photosynthetic pigment (chlorophyll a, chlorophyll b and carotenoids) were determined in treated plants with pathogens only or with formulation of T.viride and untreated control according to [20]

\section{Statistical analysis}

Data were subjected to statistical analysis and means were compared using L.S.D. test [21]

\section{Results}

\section{Pathogen city test}

Identification of isolated fungi shown in Table (1) indicated that isolated fungi were identified as Fusarium sambaucinum and Fusarium solani isolates were varied in their virulence on sugar beet

\begin{tabular}{|l|l|l|l|l|l|}
\hline \multirow{2}{*}{ Fungi } & \multirow{4}{*}{ Isolates } & \multicolumn{4}{|l}{ Damping off\% } \\
\cline { 3 - 6 } & & Pre & Post & Survival\% & $\begin{array}{l}\text { Disease index } \\
\%\end{array}$ \\
\hline \multirow{4}{*}{$\begin{array}{l}\text { Fusarium } \\
\text { sambucinum }\end{array}$} & 11 & 50 & 5 & 45 & 55 \\
\cline { 2 - 6 } & 12 & 72.5 & 5 & 22.5 & 67.5 \\
\cline { 2 - 6 } & 13 & 42.5 & 5 & 52.5 & 47.5 \\
\cline { 2 - 6 } & 14 & 67.5 & 0 & 32.5 & 64.5 \\
\hline \multirow{3}{*}{$\begin{array}{l}\text { Fusarium } \\
\text { solani }\end{array}$} & 15 & 65.5 & 5 & 30 & 65 \\
\cline { 2 - 7 } & 16 & 57.5 & 2.5 & 40 & 47.5 \\
\cline { 2 - 6 } & 17 & 57.5 & 5 & 37.5 & 52.5 \\
\cline { 2 - 6 } & 18 & 45 & 2.5 & 52.5 & 40 \\
\hline Control & & 0 & 0 & 100 & 0 \\
\hline L.S. D 5\% & 17.056 & 7.195 & 16.616 & 5.135 \\
\hline
\end{tabular}

Table 1: Pathogen city tests of Fusarium sambucinum (isolates1,2,3,4) and Fusarium solani (isolates5,6,7,8) the causal pathogens damping off and root rot oskarpoly sugar beet variety under greenhouse conditions during growing season 2009 
Page 3 of 6

oskarpolay variety the data revealed that in general there were significant difference between the isolates in both fungal species either pre-post emergence and survival compared with control data also indicate that Fusarium sambucinum. isolate No 2 was the highest virulent one in case of pre emergence damping off and less survival followed by isolate No4 and isolate No.1while isolate No 3 was the lowest pathogenic one and the highest survival $F$. solani also varied in their pathogenic isolate No 5 and 6,7 were highly pathogenic when compared with isolate 8 .

\section{In vitro antagonistic effect of $T$. Viride against the cause of sugar beet damping off and root rot disease}

Dual culture assays $T$. viride substantially reduced the growth of Fusarium sambucinum(isolates 1,2,3,4)and Fusarium solani, (isolate $5,6,7,8)$. The causal pathogens of damping off and root rot sugar beet compared with the control. The Trichoderma viride grow over and sporulated of the different Fusarium spp isolates. Resulting of complete degradation (Tables 2, 3).

\begin{tabular}{|l|l|}
\hline Isolates & Inhibition Zone \\
\hline 11 & - \\
\hline 12 & - \\
\hline 13 & \\
\hline 14 & - \\
\hline
\end{tabular}

Table 2: Reaction and antifungal of Trichoderma viride on Fusarium sambucinum(isolates1,2,3,4)causing damping off and root rot sugar beet in vitro

\begin{tabular}{|l|l|}
\hline Isolates & Inhibition Zone \\
\hline 15 & - \\
\hline 16 & - \\
\hline 17 & \\
\hline 18 & - \\
\hline
\end{tabular}

Table 3: Reaction and antifungal of Trichoderma viride on Fusarium solani (isolates, 5, 6, 7,8) causing damping off and root rot sugar beet in vitro

\begin{tabular}{|l|l|}
\hline Isolates & \% growth reduction \\
\hline 11 & 50 \\
\hline 12 & 27 \\
\hline 13 & 55 \\
\hline 14 & 37 \\
\hline
\end{tabular}

Table 4: Effect of culture filtrates of $T$. viride on Fusarium sambucinum (isolates 1,2,3,4) causing damping off and root rot sugar beet in vitro; - L.S.D. $5 \% 1.2$
Data also indicate that the $T$. viride and its filtrate inhibited the growth of the pathogens Fusarium sambucinum(isolates 1,2,3,4) and Fusarium solani, (isolates, 5, 6, 7,8) Tables (4) and (5). Isolate 1 and isolate 8 . Showed the highest percentage of growth reduction while the Isolate 2 and Isolate 5 showed the lowest percentage of growth reduction.

\begin{tabular}{|l|l|}
\hline Isolates & \% growth reduction \\
\hline 15 & 31.3 \\
\hline 16 & 35 \\
\hline 17 & 32.6 \\
\hline 18 & 39.8 \\
\hline
\end{tabular}

Table 5: Effect of culture filtrates of $T$. viride on Fusarium solani (isolates, $5,6,7,8$ ) causing damping off and root rot sugar beet in vitro; - L.S.D $5 \% 0.1 .29$

In general data also indicate that filtrate of $T$. viride showed the highest percentage of growth Fusarium sambucinum reduction compared with Fusarium solani

Data also indicate that filtrate of $T$. viride significant difference inhibited between isolates1, 2, 3, 4 of Fusarium sambucinum. Data also indicate that filtrate of $T$. viride significant difference inhibited between (Fusarium solani isolates 5, 6, 7, 8) the causal pathogen of damping off and root rot sugar beet

\section{Antagonistic effect of T. Viride against the causative pathogen of sugar-beet damping off and root rot disease under greenhouse conditions}

Data in Table $(6,7)$ indicated that soil treatment with formulation T. viride resulted in protection against the causal pathogen Fusarium sambucinum (isolates 1,2,3,4) and Fusarium solani, (isolates, 5, 6, 7,8) at the seedling stage. Minimal amount of disease were observed on plants inoculated with pathogen and bio agent compared with untreated control. $T$. viride reduced the percentages of disease incidence and disease severity of Fusarium spp. the causal pathogen of sugar beet compared with control.

The highest percentage of seedling survival and the least disease severity were associated with Isolates 3 and 8 but the lowest percentage of seedling survival and highest disease severity were associated with Isolates 2 and 5 . Data also indicate that $\mathrm{T}$. viride reduce significantly damping off and disease severity compared with control caused by the pathogens Fusarium sambucinum (isolates 1,2,3,4) and Fusarium solani, (isolate, 5, 6, 7,8)during two growing seasons.

\begin{tabular}{|l|l|l|}
\hline Treatment & 2010 & 2011
\end{tabular}


Citation: Abo-Elnaga HIG (2014) Photosynthetic Efficiency Promotion of Sugar Beet by Formulation of Trichoderma and Control of Some Sugar

\begin{tabular}{|l|l|l|l|l|l|l|l|l|}
\hline & Pre\% & Post $\%$ & Survival\% & $\begin{array}{l}\text { Disease index } \\
\%\end{array}$ & Pre\% & Post\% & Survival\% & $\begin{array}{l}\text { Disease index } \\
\%\end{array}$ \\
\hline 11 & 72.5 & 12.5 & 15 & 77.5 & 62.5 & 7.5 & 30 & 80 \\
\hline 12 & 87.5 & 10 & 2.5 & 76.2 & 82.5 & 10 & 7.5 & 70 \\
\hline 13 & 65 & 10 & 25 & 78.7 & 55 & 7.5 & 37.5 & 75 \\
\hline 14 & 92.5 & 0 & 7.5 & 63.5 & 77.5 & 0 & 22.5 & 63.5 \\
\hline $11+$ Trichoderma viride & 45 & 5 & 50 & 63.7 & 35 & 2.5 & 62.5 & 62 \\
\hline $12+$ Trichoderma viride & 70 & 5 & 25 & 61.5 & 60 & 2.5 & 37.5 & 65.2 \\
\hline $13+$ Trichoderma viride & 40 & 0 & 60 & 62.2 & 32 & 50 & 67.5 & 61 \\
\hline $14+$ Trichoderma viride & 60 & 7.5 & 32.5 & 67 & 52 & 55 & 42.5 & 54 \\
\hline Control & 0 & 0 & 100 & 0 & 0 & 0 & 100 & 0 \\
\hline L.S. D 5\% & 28.183 & 8.965 & 26.469 & 3.145 & 25.942 & 6.06 & 24.616 & 1.406 \\
\hline
\end{tabular}

Table-6: Effect of formulation of T. viride on damping off and root rot sugar beet caused by, Fusarium sambucinum (isolates 1,2,3,4) under greenhouse conditions during growing seasons 2010

Effect of treatment with formulation of $T$. viride on photosynthetic pigments ,chlorophyll a, chlorophyll b, carotenoid of sugar beet infected with, Fusarium sambucinum (isolates 1,2,3,4) and Fusarium solani, (isolates, 5, 6, 7,8) under greenhouse conditions during growing seasons 2010.

\begin{tabular}{|c|c|c|c|c|c|c|c|c|}
\hline \multirow{2}{*}{ Treatment } & \multicolumn{4}{|l|}{2010} & \multicolumn{4}{|l|}{2011} \\
\hline & Pre & Post $\%$ & Survival\% & $\begin{array}{l}\text { Disease index } \\
\%\end{array}$ & Pre\% & Post $\%$ & Survival\% & Disease index\% \\
\hline 15 & 77.5 & 7.5 & 15 & 80.62 & 75 & 5 & 20 & 75 \\
\hline 16 & 70 & 5 & 25 & 73.75 & 67.5 & 5 & 27.5 & 72 \\
\hline 17 & 72.5 & 5 & 22.5 & 75 & 70 & 5 & 25 & 73.5 \\
\hline 18 & 70 & 30 & 27.5 & 66.25 & 65 & 0 & 35 & 63.7 \\
\hline 15+Trichoderma viride & 65 & 2.5 & 32.6 & 62.5 & 62.5 & 2.5 & 35 & 65 \\
\hline 16+Trichoderma viride & 60 & 2.5 & 37.5 & 61.8 & 55 & 2.5 & 42.5 & 45 \\
\hline 17+Trichoderma viride & 62.5 & 0 & 37.5 & 61 & 60 & 2.5 & 37.5 & 61 \\
\hline 18+Trichoderma viride & 55 & 2.5 & 42.5 & 58.75 & 52.5 & 2.5 & 45 & 58.75 \\
\hline Control & 0 & 0 & 100 & 0 & 0 & 0 & 100 & 0 \\
\hline L.S. D 5\% & 17.943 & 4.865 & 15.67 & 5.072 & 12.502 & 4.865 & 13.155 & 5.043 \\
\hline
\end{tabular}

Table 7: Effect of formulation of $T$. viride on damping off and root rot sugar beet caused by Fusarium solani (isolates, 5, 6, 7,8) under greenhouse conditions during growing seasons 2010 and 2011

\begin{tabular}{|l|l|l|l|l|l|l|l|l|}
\hline \multirow{2}{*}{ Treatment } & \multicolumn{2}{|l|}{2010} & \multicolumn{2}{l|}{2011} & \multicolumn{2}{l|}{} \\
\cline { 2 - 8 } & Chl.a & Chl.b & $\begin{array}{l}\text { Total } \\
\text { chloraphall }\end{array}$ & cardonides & Chl.a & Chl.b & $\begin{array}{l}\text { Total } \\
\text { chloraphall }\end{array}$ & cardonides \\
\hline 11 & & & & & & & & \\
\hline 12 & & & & & & & \\
\hline
\end{tabular}




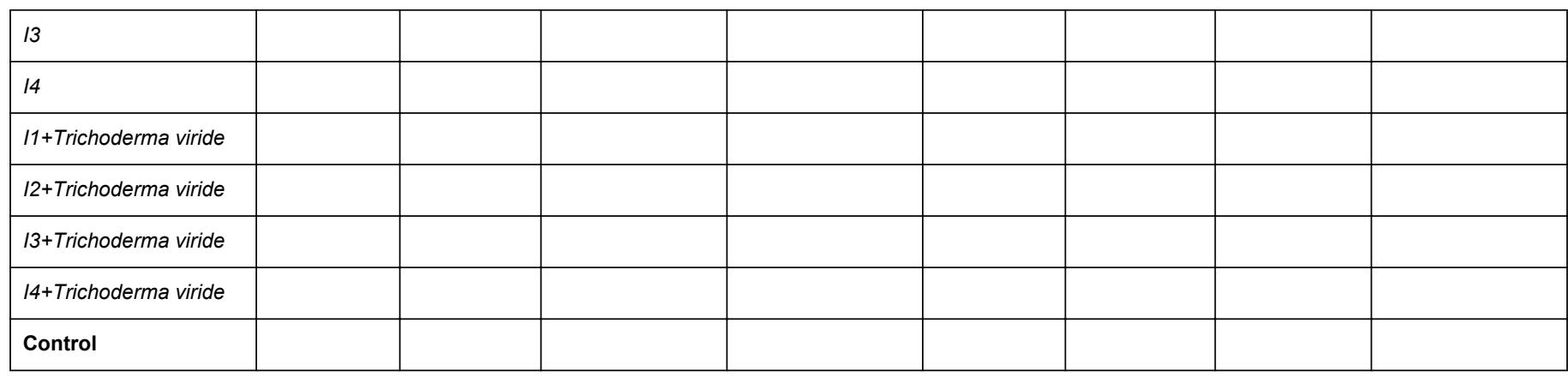

Table 8: Effect of treatment with formulation of $T$. viride on photosynthetic pigments, chlorophyll a, chlorophyll b, carotenoid of sugar beet infected with Fusarium sambucinum (isolates 1,2,3,4) under greenhouse conditions during growing seasons 2010 and 2011

\begin{tabular}{|c|c|c|c|c|c|c|c|c|}
\hline \multirow{2}{*}{ Treatment } & \multicolumn{4}{|l|}{2010} & \multicolumn{4}{|l|}{2011} \\
\hline & Chl.a & Chl.b & Total chloraphall & Cardonides & Chl.a & Chl.b & Total chloraphall & cardonides \\
\hline 15 & 0.019 & 0.105 & 0.124 & 0.046 & 0.018 & 0.01 & 0,032 & 0.043 \\
\hline 16 & 0.250 & 0.001 & 0.251 & 0.001 & 0.251 & 0 & 0.252 & 0.001 \\
\hline 17 & 0.129 & 0.004 & 0.133 & 0.056 & 0.128 & 0 & 0.132 & 0.053 \\
\hline 18 & 0.279 & 0.002 & 0.271 & 0.105 & 0.278 & 0 & 0.28 & 1.3731 \\
\hline $\begin{array}{l}\text { I5+Trichoderma } \\
\text { viride }\end{array}$ & 0.337 & 0.189 & 0.526 & 0.165 & 0.336 & 0.19 & 0.524 & 0.164 \\
\hline $\begin{array}{l}\text { 16+Trichoderma } \\
\text { viride }\end{array}$ & 0.319 & 0.235 & 0.554 & 0.159 & 0.138 & 0.23 & 0.372 & 0.158 \\
\hline $\begin{array}{l}17+\text { Trichoderma } \\
\text { viride }\end{array}$ & 0.299 & 0.243 & 0.545 & 0.128 & 0.298 & 0.24 & 0.541 & 0.127 \\
\hline $\begin{array}{l}\text { 18+Trichoderma } \\
\text { viride }\end{array}$ & 0.643 & 0.003 & 0.643 & 0.004 & 0.643 & 0 & 0.0643 & 0.004 \\
\hline Control & 0.743 & 0.222 & 0.963 & 0.169 & 0.743 & 0.22 & 0.967 & 0.169 \\
\hline
\end{tabular}

Table 9: Effect of treatment with formulation of $T$. viride on photosynthetic pigments, chlorophyll a, chlorophyll b, carotenoid of sugar beet infected with, Fusarium sambucinum (isolates 1,2,3,4) under greenhouse conditions during growing seasons 2010 Discussion

Fusarium sambucinum (isolates 1,2,3,4) and Fusarium solani, (isolates $5,6,7,8$ ) cause damping of $f$ and root rot of sugar beet this results agree with [1-2].

The biological control of plant pathologic fungi has received considerable attention as an alternative strategy. The use of the antagonistic properties of Trichoderma spp in the biological control of many plant diseases has been a subject of many studies [22-3]in vitro culture filtrate of $T$.viride varied decrease \% growth reduction of Fusarium sambucinum (isolates 1,2,3,4) and Fusarium solani, (isolates, $5,6,7,8)$.The suppressive effect varied according to the antagonistic filtrate. These results agree with Chet and Baker1981 [23].

Trichoderma spp is known to have the ability to produce some extra cellular, lactyic enzymes that are involved in the process of antagonism against a variety of pathogenic organisms [24]. Biocontrol technologies have gained momentum in disease control of crop plants in recent times as these technologies not only minimize of replace the usages of harmful chemical pesticides but also found to be cheaper and efficient in certain disease control programmers. Successful use of fungal bio control agents like Trichoderma spp. for the agents that commercially produced to prevent development of several soil pathogenic fungi $[4,5,6]$. Different mechanisms control soil born disease caused by pathogens like Rhizoctonia, Sclerotium, Fusarium, Pythium and Phophthora in several crops have been reported [7] therefore using biological control such as T.viride which is one the efficient bio control have been suggested as being responsible for their bio-control activity which includes mycoparasitism, antibiosis, competition for nutrients and space and secretion of chitinolytic enzymes [8]. The mass production systems should be complete with industrial and commercial development methods and field application [9]. Trichoderma spp. can be formulated as pellets [10] dusts an powders [11] Formulation T.viridi have a positive effect against the tested pathogenic sugarbeet could be explained by hyper parasitism. Treatment the soil with formulation of T.viridi reduce damping off and root rot caused by Fusarium sambucinum (isolates 1,2,3,4) and Fusarium solani, (isolates 5,6,7,8) compared with control and untreated and untreated with T.viridi these results agreement with those recorded by $[25,26,3]$. They reported that the bio control agent characterized by faster metabolic rates anti-microbial metabolites and physiological conformation are key factors which contribute to 
antagonism of these fungi. The antagonistic effect of bio-control agent also may be due to mycoparasitism, spatial and nutrient competition antibiosis by enzymes and secondary metabolites and induction of plant defense system are typical bio-control actions of these fungi. The obtained results revealed that frequency of some saprophytic fungi such as A.niger, Aspergillus spp., Penicillium spp. and Trichoderma spp. as well as pathogenic. Fungi of Fusarium spp., F. solani and $R$. solani in treated rhizosphere of sugar beet were affected by T.viride. The saprophytic mycoflora could be playing an important role in increasing the antagonistic effect of the bio control agent [8]. Photosynthetic pigments chlorophyll $\mathrm{a}$ and chlorophyll $\mathrm{b}$ and carotenoids were lower in the infected leaves than healthy one and in infected leaves than healthy one and in infected leave and treated the soil with formulation of T.viride. The occurrence of changes in leaf color as a result of infection by most disease was proved by many investigation. The chlorophyll pigment plays an important role in metabolic activity in the plant extremely affected by disease incidence [12] stated that striking changes in the amount and distribution of photosynthetic pigment resulted from the infection by obligated parasite.

\section{References}

1. El-Ganaieny RMA, Mohamed HY, Omaran AA, Gebriel MY (2002) Effect of some Agriculture practices on the control of damping off and root rot. Diseases of sugar beet. The 3nd Sciences, Assiut, Oct. 2002.

2. El-Kazzaz MK, El-Fadly GB, Hassan MAA, El-Kot GNN (2008) Identification of some Fusarium spp. Using Molecular biology techniques. Egypt Journal of Phytopathology , 36: 57-69.

3. Abd-El-Fattah AI, Abd-El-Khair H, Wafaa MA El-Nagdi (2012)Interaction of Fusarium solani and Meloidogyne on sugar beet and their control using Trichoderma viride .Journal of Applied Science Research8: 3166-3175.

4. Ozby N, Newan SE (2004) Biological control with Trichoderma spp. With Emphasis on T. harzianum. Pak. J. Biol. Sci. 7: 478-484.

5. Shalini, Narayan KP, Lata, Kotasthane AS (2006) Genetic relatedness among Trichoderma isolates inhibiting a pathogenic fungi Rhizoctonia solani Afr. J. Biotechnol 6: 580-584.

6. Yadav J, Verma JP, Tiwari KN (2011) Plant Growth Promoting Activities of Fungi and their Effect on Chickpea Plant Growth. Asian Journal of Biological Sciences 4: 291-299.

7. Cook RJ, Baker KF (1983) The nature and Practice of biological control of plant pathogens. APS Books, USA: 539.

8. Harmen GE (2000) Myths and dogmas of bio-control: changes in perceptions derived from research on Trichoderma harzianum T22. Plant Dis 84: $377-391$.

9. Ramanujam B, Prasad RD, Sriram S, Rangeswaran R (2010) Mass production, formulation, quality control and delivery of Trichoderma for plant disease management .The Journal of plant protection Sciences 2: $1-8$.
10. Papaviza GC, lewis JA (1989) Effect of Gliocladium and Trichoderma on damping off and blight of snap bean caused by Sclerotium rolfsii in the greenhouse. Plant Pathology 38: 277-286.

11. Nelson ME, Powelson ML (1988) Biological control of grey mold snap beans by Trichoderma hamatum. Plant Disease 72: 727-29.

12. Wood RKS (1967) Physiological plant pathology. Blackwell Scientific Publication Ltd. Oxford and Edinburgh.

13. Booth C (1971) The Genus Fusarium. Commonwealth Mycological Institute Krew, Surry, United Kingdom.

14. Moubsher AH (1993) Soil fungi in Qatar and other Arab countries. The Scientific and Applies Research center, University of Qatar: 566.

15. Fahi MM, Kararah MA, EL-Gharbawi AA, Abada KAM (1981) Studies on fungi causing root-rot sugar beet with special reference to Sclerotium rolfsii. Egypt of Journal Phytopathology 13: 254 -255.

16. Elad Y, Chet I (1983) Improved selective medium for isolation of Trichoderma spp. from soil. Phytoparasitica 11: 55-58.

17. Coskuntuna A, Ozer NN (2008) Biological control of onion basal rot disease using Trichoderma harizanum and induction of antifungal compound $s$ in onion set following seed following seed treatment. Crop Prot. 27: 330-336.

18. Kucuk C, Kivan M (2003) Isolation of Trichoderma I spp. and of their antifungal activity determination of their antifungal biochemical and physiological Lectures. Turk. J. Biol. 27: 247-253.

19. Kucuk C, Kivan M (2004) In vitro antifungal activity of strains of Trichoderma harizanumTurk, J. Biol., 28: 111-115.

20. Von Wettstein D (1957) [Chlorophyll lethals \& submicroscopic morphological changes in plastids]. See comment in PubMed Commons below Exp Cell Res 12: 427-506.

21. Gomez KA, Gomez AA (1984) Statistical procedures for Agricultural research. John Willey. New York: 68.

22. El-Shanshoury A, Agwa HE, Osman MS, El-Halmouch YH (2000) Antifungal activities of Streptomyces anulatus S.chromofuscue,S.albaduncus and Trichoderma viride against Corcospora baticola and Alternaria alternate causing sugsrbeet leaf spot . Bulltein of the Faculty of Science, Assiut University.

23. Ushamalini CK, Rajappan, Gangalharan K (1997) Inhibition of Macrophomina phaselonia and Fusarium oxysporium f. spp. tracheiphilum by antagonists under in vitro condition Pl. Dis. Res 12: 168-170.

24. Mukhapadhyay AN (1997) Biological management of soil-borne plant disease management for sustainable Agriculture: 10-15.

25. Viterbo A, Ramot O, Chemin L, Chet I (2002) Significance of lytic enzymes from Trichoderma spp. in the biocontrol of fungal plant pathogens. See comment in PubMed Commons below Antonie Van Leeuwenhoek 81: 549-556.

26. Verma M, Brar SK, Tyagi RD, Surampalli RY, Valero JR (2007) Antagonistic fungi, Trichoderma spp:Panoply of biological control. Biochemical Engineering Journal 37: 1-20. 